\title{
Development of Treatment for Pulmonary Alveolar Proteinosis
}

Key words: pulmonary surfactant, ambroxol, lung lavage, granulocyte-macrophage colony-stimulating factor (GM-CSF)

Pulmonary alveolar proteinosis (PAP) was first reported as an independent disease in 1958 by Rosen and colleagues (1). They described the histological appearance of slight interstitial inflammation and the marked periodic acid Schiff (PAS)positive proteinaceous alveolar deposits, which were confirmed as alveolar accumulation of the components of pulmonary surfactant morphologically, immunologically, and biochemically (2-5). In addition, serum levels of surfactant protein (SP)-A and $-\mathrm{D}$, components of the accumulated surfactant, are quite high possibly because of their leakage from alveolar spaces to bloodstream $(5,6)$. Clinical courses of PAP were variable ranging from spontaneous resolution to death with respiratory failure or uncontrolled infection. According to Seymour and Presneill, 24 of 303 cases in collected reports (7.9\%) were described as cases of spontaneous improvement (7).

In the past, treatment for PAP has included antibiotics, corticosteroids, potassium iodide, and trypsin with variable effects (8-10). A single case was reported outside Japan in which ambroxol improved PAP (11). In addition, recently several reports in Japan stated that ambroxol was effective for PAP (1214). Although the mechanisms responsible for the effectiveness of ambroxol for PAP are still not understood, Suyama and colleagues suggested that alveolar type II cells stimulated with ambroxol could effect the surfactant metabolism of alveolar macrophages (13). It was reported that ambroxol stimulates surfactant secretion from alveolar type II cells, therefore, ambroxol could be effective for replacement of the degenerated surfactant to the intact form. In this issue, Hashizume reports a case of PAP in which ambroxol was effective, with a discussion of the current concepts on pathogenesis and diagnosis (14).

See also $\mathrm{p} 1175$.

Now, the prognosis of this disease is improved by removal of accumulating surfactant with whole lung lavage method and the survival rate at 5 years of cases with therapeutic lavage is $94 \%$ compared to $85 \%$ in those without therapeutic lavage (7). Whole lung lavage is generally done with up to $3 l$ of saline via a double lumen endotracheal tube under general anesthesia. Recently, some modifications for whole lung lavage have been carried out (15-17). Although some complications including hypoxemia due to a shunt created by filled alveoli and hemodynamic changes due to single lung ventilation may occur, invasive monitoring is unnecessary in most cases and only one patient died related to this procedure (7).

Recently, there has been a discovery in understanding the pathogenesis of PAP in gene-targeted mice lacking granulocyte-macrophage colony-stimulating factor (GM-CSF) $(18,19)$. In addition, Tanaka et al (20) and Kitamura et al (21) identified an autoantibody against GM-CSF in the serum and bronchoalveolar lavage fluid of patients with idiopathic PAP but not with congenital or secondary PAP. Seymour and colleagues reported that the response rate to the treatment of idiopathic PAP with GM-CSF was $43 \%$ (22). GM-CSF administration, therefore, may be a possible potential treatment for idiopathic PAP in future.

Masanori SHIRATORI, MD, PhD and
Hiroki TAKAHASH, MD, PhD
The Third Department of Internal Medicine,
Sapporo Medical University School of Medicine,
West 16, South 1, Chuo-ku, Sapporo 060-8543

\section{References}

1) Rosen $\mathrm{SH}$, Castleman B, Liebow AA. Pulmonary alveolar proteinosis. $\mathrm{N}$ Engl J Med 258: 1123-1142, 1958.

2) Costello JF, Moriarty DC, Branthwaite MA, Turner-Warwick M, Corrin B. Diagnosis and management of alveolar proteinosis: the role of electron microscopy. Thorax 30: 121-132, 1975.

3) Singh G, Katyal SL, Bedrossian CW, Rogers RM. Pulmonary alveolar proteinosis. Staining for surfactant apoprotein in alveolar proteinosis and in conditions simulating it. Chest 83: 82-86, 1983.

4) Honda Y, Takahashi H, Shijubo N, Kuroki Y, Akino T. Surfactant proteinA concentration in bronchoalveolar lavage fluids of patients with pulmonary alveolar proteinosis. Chest 103: 496-499, 1993.

5) Honda Y, Kuroki Y, Matsuura E, et al. Pulmonary surfactant protein D in sera and bronchoalveolar lavage fluids. Am J Respir Dis 152: 1860-1866, 1995.

6) Kuroki Y, Takahashi T, Chiba H, Akino T. Surfactant proteins A and D: disease markers. Biochim Biophys Acta 1408: 334-345, 1998.

7) Seymour JF, Presneill JJ. Pulmonary alveolar proteinosis: progress in the first 44 years. Am J Respir Crit Care Med 166: 215-235, 2002.

8) Davidson JM, Macleod WM. Pulmonary alveolar proteinosis. Br J Dis Chest 63: 13-28, 1969.

9) Larson RK, Gordinier R. Pulmonary alveolar proteinosis: report of six cases, review of the literature and formulation of a new theory. Ann Intern Med 62: 292-312, 1965.

10) Riker JB, Wolinsky H. Trypsin aerosol treatment of pulmonary alveolar proteinosis. Case report. Am Rev Respir Dis 108: 108-113, 1973.

11) Diaz JP, Manresa Presas F, Benasco C, Guardiola J, Munoz L, Clariana A. Response to surfactant activator (ambroxol) in alveolar proteinosis. Lancet I: 1023, 1984.

12) Horiguchi $T$, Hanazono $K$, Takeuchi $N$, et al. Pulmonary alveolar 
proteinosis successfully treated by oral administration of ambroxol: a case report. Nippon Kyobu Rinsho 51: 1042-1046, 1992 (in Japanese, Abstract in English).

13) Suyama H, Burioka N, Sako T, et al. Pulmonary alveolar proteinosis treated with oral ambroxol hydrochloride and bronchoalveolar lavage. Yonago Acta Med 42: 175-178, 1999.

14) Hashizume T. Pulmonary alveolar proteinosis successfully treated with ambroxol. Intern Med 41: 1175-1178, 2002.

15) Hammon WE, McCaffree DR, Cucchiara AJ. A comparison of manual to mechanical chest percussion for clearance of alveolar material in patients with pulmonary alveolar proteinosis (phospholipidosis). Chest 103: 14091412, 1993.

16) Shah PL, Hansell D, Lawson PR, Reid KB, Morgan C. Pulmonary alveolar proteinosis: clinical aspects and current concepts on pathogenesis. Thorax 55: 67-77, 2000.

17) Cohen ES, Elpern E, Silver MR. Pulmonary alveolar proteinosis causing severe hypoxemic respiratory failure treated with sequential whole-lung lavage utilizing venovenous extracorporeal membrane oxygenation: a case report and review. Chest 120: 1024-1026, 2001.
18) Stanley E, Lieschke GJ, Grail D, et al. Granulocyte/macrophage colonystimulating factor-deficient mice show no major perturbation of hematopoiesis but develop a characteristic pulmonary pathology. Proc Natl Acad Sci USA 91: 5592-5596, 1994.

19) Dranoff G, Crawford AD, Sadelain M, et al. Involvement of granulocytemacrophage colony-stimulating factor in pulmonary homeostasis. Science 264: 713-716, 1994.

20) Tanaka N, Watanabe J, Kitamura T, Yamada Y, Kanegasaki S, Nakata K. Lungs of patients with idiopathic pulmonary alveolar proteinosis express a factor which neutralizes granulocyte-macrophage colony stimulating factor. FEBS Lett 442: 246-250, 1999.

21) Kitamura $T$, Tanaka $\mathbf{N}$, Watanabe $\mathbf{J}$, et al. Idiopathic pulmonary alveolar proteinosis as an autoimmune disease with neutralizing antibody against granulocyte/macrophage colony-stimulating factor. J Exp Med 190: 875$880,1999$.

22) Seymour JF, Presneill JJ, Schoch OD, et al. Therapeutic efficacy of granulocyte-macrophage colony-stimulating factor in patients with idiopathic acquired alveolar proteinosis. Am J Respir Crit Care Med 163: 524-531, 2001. 